\title{
Uji Adaptasi Galur Mutan Harapan Kedelai Hitam DT17 G1 dan DT19 G1-2
}

\section{Adaption Test of Promising Black Soybean Mutant Line DT17 G1 and DT19 G1-2}

\section{Tarmizi dan Lilik Harsanti}

Pusat Aplikasi Isotop dan Radiasi - Badan Tenaga Nuklir Nasional

Jl. Lebak Bulus Raya No. 49 Pasar Jumat Jakarta Selatan 17020

Email : tarmizi.mizi@batan.go.id

\begin{abstract}
ABSTRAK
Upaya peningkatan produksi kedelai hitam (Glycine max L. Merr.) di dalam negeri untuk ketersediaan bahan baku industri pangan adalah penyediaan varietas unggul kedelai produksi tinggi, berumur genjah, tahan hama dan penyakit utama. Varietas unggul kedelai hitam sebagai bahan baku kecap masih sangat sedikit, untuk itu BATAN ikut berkontribusi untuk merakit, meneliti dan mengembangkan varietas unggul kedelai hitam. Metode untuk meningkatkan variasi genetik dalam mendapatkan varietas unggul diantaranya adalah dengan teknik nuklir menggunakan sinar gamma sehingga terjadi mutasi. Varietas Cikuray telah diiradiasi sinar $\gamma$ Co-60 dengan dosis 200 Gy pada tahun 2008 dan terpilih 5 galur mutan harapan kedelai hitam. Uji adaptasi sudah dilakukan di 10 lokasi melalui Konsorsium Kedelai Nasional, dengan tambahan 5 galur dari Balai Penelitian Aneka Kacang dan Umbi (BALITKABI) Malang, 5 galur dari Universitas Padjadjaran (UNPAD) dan 2 varietas kontrol (Cikuray dan Detam 1). Dari analisis keragaman menunjukkan seluruh komponen genotip menunjukan beda nyata pada taraf uji F 5\%. Interaksi genotip dengan lingkungan (linier) yang nyata menunjukkan bahwa peningkatan hasil galur sejalan dengan meningkatnya produktivitas lingkungan. Berdasarkan uji $\mathrm{F}$ pada simpangan gabungan menunjukkan beda nyata pada taraf 5\%. Galur DT 17 G1 dan DT 19 G1-2 memiliki daya stabilitas dan adaptabilitas. Genotip yang dinilai stabil sekaligus memiliki rata-rata hasil biji lebih tinggi di 10 lokasi adalah galur DT 17 G1 dan mampu berproduksi optimal pada rentang lingkungan yang relatif luas dibandingkan dengan galur lainnya, termasuk galur DT 19 G1-2 meskipun yang tidak dinilai stabil. Galur DT 19 G1-2 mencapai hasil biji tertinggi, juga memiliki nilai koefisien regresi tertinggi dan positif, artinya galur tersebut beradaptasi khusus untuk dikembangkan pada daerah yang memiliki tingkat produktivitas lahan yang subur. Produktivitas galur DT 19 G1-2 rata-rata 2,42 t/ha dengan potensi 3,17 t/ha dan galur DT 17 G1 2,32 t/ha dengan potensi 3,04 t/ha. Ukuran biji kedua galur lebih besar dari pada induknya Cikuray. Berdasarkan data dan hasil pengujian tersebut, maka galur DT17 G1 dan DT19 G1-2 dapat diajukan untuk dievaluasi dan diusulkan menjadi varietas unggul baru kedelai hitam.
\end{abstract}

Kata kunci : Kedelai hitam, teknik mutasi, iradiasi gamma, uji adaptasi

\begin{abstract}
The efforts to increase black soybean production (Glycine max L. Merr.) in the country, for the availability of raw materials of the food industry is provision of high yielding superior soybean varieties, mature ages, and resistant to pests and diseases. Soybean superior varieties as raw material of soy sauce are still very little. Based on that reason, BATAN contributes to assembling, researching and developing superior varieties of black soybeans. One of the methods to increase genetic variation in obtaining superior varieties is nuclear technique using gamma rays that yielding in mutation. The Cikuray variety has been irradiated using gamma rays a dose of $200 \mathrm{~Gy}$ in 2008 and selected 5 promising black soybean mutant lines. Adaptation test has been conducted at 10 locations through National Soybean Consortium, with additional 5 lines from the Indonesian Legumes and Tuber Crops Researach Institute (BALITKABI) Malang, 5 lines of Padjadjaran University (UNPAD) and 2 national varieties as control (Cikuray and Detam 1). From the analysis of diversity, all components of genotype show significant difference at a rate of 5\% of $\mathrm{F}$ test. Genotype interaction with the environment (linear) indicates that the increase of line result is in line with the increase of environmental productivity. Based on the F test on the combined deviation, it shows significant difference at a rate of 5\%. DT17 G1 and DT19 G1-2 line has stability and adaptability. The genotype which rated stable as well as having higher seed yield than average at the 10 location is a DT17 G1 line. The line is capable of optimum production in the range of relatively broad environment compared to other lines, including the DT19 G1-2 line although it is not rated stable. DT19 G1-2 line reaches the highest seed yield, and also has the highest and positive coefficient regression value. It means
\end{abstract}




\begin{abstract}
that the line adapt specifically to developed in areas that have fertile land productivity level. The productivity of the DT19 G1-2 line is an average of $2.42 \mathrm{t} / \mathrm{ha}$ with a potential of $3.17 \mathrm{t} / \mathrm{ha}$ and DT17 G1 line is $2.32 \mathrm{t} / \mathrm{ha}$ with a potential of $3.04 \mathrm{t} / \mathrm{ha}$. The size of both lines is larger than its parent, Cikuray. Based on the data and the test results, then the DT17 G1 and DT19 G1-2 line can submitted to be evaluated and proposed to be new superior varieties of black soybeans.
\end{abstract}

Keywords : Black soybean, mutation technique, gamma irradiation, adaption test.

\section{PENDAHULUAN}

Kedelai hitam adalah salah satu varietas dari kedelai (Glycine max L. Merr.). Kedelai hitam secara botani dan nutrisi memiliki banyak kesamaan dengan kedelai kuning, namun warnanya yang hitam menjadikan kedelai ini memiliki pemanfaatan yang spesifik. Kecap, tauco, tempe, tahu, susu kedelai dan lain-lain adalah beberapa contoh produk olahan yang dapat dibuat dari kedelai hitam, namun yang paling sering adalah kecap. Perbedaan dengan kedelai lainnya hanya pada warna kulit bijinya saja, rasa, tekstur dan warna bagian dalam biji tetap sama [1].

Kedelai berbiji hitam lebih disukai untuk bahan baku kecap karena dapat memberi warna hitam alami pada produknya [2]. Kecap merupakan produk fermentasi kedelai yang digunakan sebagai bahan penyedap dan pemberi warna pada makanan. Namun, jumlah varietas kedelai berbiji hitam lokal dan unggul sangat terbatas, varietas Merapi, Cikuray, Mallika dan umumnya berbiji kecil. Varietas Detam 1 dan Detam 2 merupakan varietas unggul kedelai hitam berbiji besar yang telah dilepas pada tahun 2008 dengan potensi hasil 3,0-3,5 t/ha dan kadar protein $45 \%$. Kedua varietas tersebut sesuai untuk bahan baku kecap [3]. Namun demikian perakitan varietas unggul baru perlu terus diupayakan.

Kedelai hitam banyak mengandung anthosianin. Anthosianin tinggi mempunyai antivitas antioksidan yang tinggi, juga mempunyai kandungan 1.1-diphenyl-2-picrylhydrazyl $(\mathrm{DPPH})$ dan $\mathrm{O}_{2}$. Ekstrak kedelai hitam yang direbus mengandung liver tert-butyl hydroperoxide (t-BuOO) yang tinggi dan mencegah kuat terbentuknya thiobarbituric acidreactive substance (TBARS) yang menyebabkan gangguan pada hati [4]. Kedelai hitam penting untuk diperhatikan karena merupakan bahan dari produk makanan sehat dari kedelai. Pigmen anthosianin pada kedelai hitam mempunyai antioksidan yang lebih tinggi dibandingkan tokoperol. Mengingat banyaknya manfaat kedelai hitam, oleh karenanya perlu peningkatan produksi kedelai hitam.

Umur panen kedelai yang super genjah sangat menguntungkan karena akan dapat dengan mudah mengisi pola tanam padi-padi-kedelai. Diakhir musim hujan sesudah panen padi periode tanam kedua, biasanya petani sudah tidak lagi menanami lahannya karena segera akan masuk musim kemarau, tetapi dengan adanya varietas super genjah petani masih bisa memanfaatkan lahannya dengan optimal [5]. Di daerah tropis seperti Indonesia, umur tanaman kedelai genjah berkisar 75 hari [6]. Kedelai dengan biji besar sangat diminati oleh produsen tempe, karena kedelai dengan biji besar mempunyai rendemen yang tinggi dibandingkan dengan kedelai berbiji kecil, juga diharapkan kedelai berbiji besar dapat bersaing dengan kedelai impor [7].

Salah satu cara untuk perbaikan varietas unggul adalah melalui pemuliaan tanaman dengan teknik mutasi radiasi. Pemuliaan tanaman adalah kegiatan mengubah susunan genetik individu maupun populasi tanaman untuk suatu tujuan sehingga diperoleh tanaman yang lebih bermanfaat. Susunan genetik individu maupun populasi tanaman dapat diubah antara lain melalui dengan mutasi genetik. Mutasi genetik tanaman dapat diinduksi dengan menggunakan mutagen seperti radiasi sinar gamma. Bagian tanaman yang diradiasi biasanya adalah benih yang akan ditumbuhkan. Pemuliaan tanaman secara mutasi disebut pemuliaan mutasi. Pemuliaan mutasi mempunyai karakter spesifik antara lain sangat efektif untuk merubah sedikit sifat dalam perbaikan varietas tanaman [8].

\section{BAHAN DAN METODE}

Pada tahun 2008 sebanyak 1000 gram benih kedelai varietas Cikuray diiradiasi dengan sinar $\gamma$ yang berasal dari Cobalt 60 dengan dosis $200 \mathrm{~Gy}$ dan laju dosis pada saat radiasi 700 Gy/jam. 
Tanaman $\mathrm{M}_{1}$ dipanen secara individual dan ditanam pada generasi $\mathrm{M}_{2}$ secara pedigree. Pada generasi $\mathrm{M}_{2}, \mathrm{M}_{3}$ dan $\mathrm{M}_{4}$ dilakukan seleksi positif dengan memilih tanaman yang berumur genjah dan berpenampilan baik. Tanaman berpenampilan baik dicirikan dengan tanaman kokoh dan batang kuat, polong banyak, tanaman tumbuh sehat dan bagus serta tahan terhadap serangan hama dan penyakit. Pemilihan dan seleksi juga berdasarkan fenotip dan agronomik.

Galur-galur mutan terpilih terus dimurnikan pada generasi berikutnya sampai generasi $\mathrm{M}_{4}$ dan $\mathrm{M}_{5}$ dimana tidak lagi terjadi segregasi dan tanaman sudah tumbuh seragam serta panen serentak untuk tiap-tiap galur terpilih. Pada generasi $\mathrm{M}_{5}$ tersebut itulah terpilih sebanyak 28 galur mutan unggulan dan berproduksi lebih tinggi dari varietas tetua dan kontrolnya. Selanjutnya dilakukan uji daya hasil pendahuluan (UDHP) di kebun percobaan Citayam Depok Jawa Barat sebanyak 28 galur mutan untuk melihat produksi per hektar dari masing-masing galur terpilih tersebut di skala lapang. Uji daya hasil lanjut (UDHL) di kebun percobaan Cibadak Pacet Jawa Barat, untuk memilih galur-galur mutan kedelai hitam dengan kriteria terbaik, untuk dilanjutkan dengan uji adaptasi. Dari uji daya hasil lanjut terpilih 5 galur mutan harapan kedelai hitam berumur genjah, berproduksi tinggi, toleran terhadap serangan hama dan penyakit yang siap untuk dilakukan uji adaptasi.

Galur harapan kedelai hitam yang diuji adaptasi berjumlah 15 galur, 5 galur dari PAIRBATAN yaitu : DT16 G1, DT15 G1, DT13 G1-2, DT19 G1-2, DT17 G1, 5 galur dari Balai Penelitian Tanaman Aneka Kacang dan Umbi
(BALITKABI) yaitu : H1-1051, H2-662, H31811, H4-1844, H5-2205 dan 5 galur dari Fakultas Pertanian Universitas Padjadjaran (UNPAD) yaitu : UNPAD CK12, UNPAD KA2, UNPAD CK5, UNPAD KA6, UNPAD CK6 dan 2 varietas pembanding yaitu varietas Cikuray sebagai tetua dan varietas Detam 1 sebagai kontrol nasional.

Metode percobaan menggunakan rancangan acak kelompok (RAK) dengan 4 ulangan, ukuran petak $3 \times 4 \mathrm{~m}$, jarak tanam 40x15 cm. Parameter pengamatan meliputi: umur berbunga, umur masak, jumlah tanaman dipanen, tinggi tanaman, jumlah polong, hasil biji, bobot 100 biji serta sifat kualitatif : warna hipokotil, warna bunga, warna daun, warna bulu, warna kulit biji, warna polong masak, bentuk biji, warna hilum dan tipe tumbuh.

Pemupukan dengan $50 \mathrm{~kg}$ Urea, $100 \mathrm{~kg}$ SP36 dan $75 \mathrm{~kg} \mathrm{KCl} / \mathrm{ha}$ diberikan secara larikan. Perawatan benih (seed treatment) dengan insektisida 'Marshal'. Pengolahan tanah, pengendalian gulma, hama dan penyakit dilakukan secara optimal.

\section{HASIL DAN PEMBAHASAN}

\section{Uji adaptasi}

Pengujian adaptasi merupakan kegiatan akhir dari beberapa program pemuliaan tanaman yaitu untuk mengetahui tingkat produktivitas dan kemampuan galur-galur mutan harapan dalam beradaptasi diberbagai lokasi di Indonesia. Setelah dilakukan seleksi, observasi, pemurnian, uji daya hasil pendahuluan dan uji daya hasil lanjutan. Hal ini sebagai persyaratan jika akan diajukan ke Tim Penilai dan Pelepas Varietas Tanaman Pangan

Tabel 1. Lokasi uji adaptasi galur mutan harapan kedelai hitam di 10 lokasi

\begin{tabular}{clccccc}
\hline No & \multicolumn{1}{c}{ Lokasi } & $\begin{array}{c}\text { Tanggal } \\
\text { Tanam }\end{array}$ & Musim & $\begin{array}{c}\text { Jenis } \\
\text { Tanah }\end{array}$ & $\begin{array}{c}\text { Jenis } \\
\text { Lahan }\end{array}$ & $\begin{array}{c}\text { Elevasi } \\
\mathrm{m} \text { dpl }\end{array}$ \\
\hline 1 & Cibadak Cianjur Jawa Barat & $07-2-2012$ & MH & Regosol & Sawah & 700 \\
2 & Citayam Depok Bogor Jawa Barat & $12-2-2012$ & MH & Latosol & Sawah & 40 \\
3 & Kadipaten Majalengka Jawa Barat & $25-2-2012$ & MH & Regosol & Sawah & 50 \\
4 & Playen Yogyakarta Jawa Tengah & $02-3-2012$ & MH & Latosol & Tegalan & 200 \\
5 & Tambak Rejo Banyuwangi Jatim & $15-3-2012$ & MH & Latosol & Sawah & 168 \\
6 & Kedungbanteng Madiun Jatim & $17-6-2012$ & MK & Vertisol & Sawah & 62 \\
7 & Wonokerto Ngawi Jawa Timur & $25-6-2012$ & MK & Regosol & Sawah & 86 \\
8 & Plumbon Cirebon Jawa Barat & $02-7-2012$ & MK & Regosol & Sawah & 50 \\
9 & Wanasari Indramayu Jawa Barat & $15-7-2012$ & MK & Regosol & Sawah & 20 \\
10 & Karawang Timur Jawa Barat & $27-7-2012$ & MK & Latosol & Sawah & 10 \\
\hline
\end{tabular}

Keterangan : MH : Musim Hujan, MK : Musim Kemarau

m dpl : meter di atas permukaan laut 
(TP2V) Kementrian Pertanian dan menjadi varietas unggul baru.

Uji adaptasi dilaksanakan melalui program konsorsium dari Badan Litbang Kementerian Pertanian, dan pengujian ini bekerja sama dengan Balai Penelitian Tanaman Aneka Kacang dan Umbi (BALITKABI) Malang dan Fakultas Pertanian Universitas Padjadjaran (UNPAD) Bandung Jawa Barat. Pengujian juga bekerjasama dengan Direktorat Perbenihan Tanaman Pangan serta Balai Pengawasan dan Sertifikasi Benih (BPSB) di masing-masing daerah untuk penanaman. Lokasi pengujian adaptasi tertera pada Tabel 1 . dibandingkan dengan kontrol varietas Cikuray $(1,86 \mathrm{t} / \mathrm{ha})$ dan tidak berbeda nyata dengan Detam 1 (2,79 t/ha), sedangkan galur DT17 G1 memiliki produksi biji 2,63 t/ha berbeda nyata lebih tinggi dibandingkan dengan kontrol varietas Cikuray dan tidak berbeda nyata dengan varietas Detam 1 kontrol nasional. Rata-rata tingkat produksi biji dilokasi ini mencapai 2,14 t/ha. Uji adaptasi genotip kedelai hitam lokasi di Cianjur Jabar pada Gambar 1.

Lokasi Bogor Jawa Barat semua galur mutan kedelai hitam memiliki produksi biji rendah kisaran antara 1,19-1,76 t/ha. Hasil analisis ragam menunjukkan bahwa uji $\mathrm{F}$ berbeda nyata pada

Tabel 2. Produksi biji uji adaptasi pada musim hujan (MH) di 5 lokasi percobaan

\begin{tabular}{|c|c|c|c|c|c|c|c|}
\hline \multirow{3}{*}{ No } & \multirow{3}{*}{$\begin{array}{l}\text { Nama galur/ } \\
\text { varietas }\end{array}$} & \multicolumn{5}{|c|}{ PRODUKSI BIJI (t/ha) } & \multirow{3}{*}{$\begin{array}{c}\text { Rerata } \\
\text { gabungan } \\
\text { (t/ha) }\end{array}$} \\
\hline & & \multicolumn{5}{|c|}{ MH (2010) } & \\
\hline & & $\begin{array}{c}\text { Cianjur } \\
\text { Jawa Barat }\end{array}$ & $\begin{array}{c}\text { Bogor } \\
\text { Jawa Barat }\end{array}$ & $\begin{array}{l}\text { Majalengka } \\
\text { Jawa Barat }\end{array}$ & $\begin{array}{l}\text { Yogyakarta } \\
\text { Jawa Tengah }\end{array}$ & $\begin{array}{l}\text { Banyuwangi } \\
\text { Jawa Timur }\end{array}$ & \\
\hline 1 & H1-1051 & 1,97 def & $1,60 \mathrm{abc}$ & 1,92 cde & $2,30 \mathrm{de}$ & 2,41 bcdef & 2,05 \\
\hline 2 & H2-662 & $1,78 \mathrm{f}$ & $1,65 \mathrm{abc}$ & $2,00 \mathrm{~cd}$ & $2,50 \mathrm{~cd}$ & 2,18 ef & 2,02 \\
\hline 3 & H3-1811 & $1,98 \mathrm{def}$ & $1,47 \mathrm{bc}$ & $2,08 \mathrm{c}$ & $2,90 \mathrm{a}$ & $2,60 \mathrm{abc}$ & 2,21 \\
\hline 4 & H4-1844 & $1,96 \mathrm{def}$ & $1,76 \mathrm{a}$ & $2,08 \mathrm{c}$ & $2,45 \mathrm{~cd}$ & $2,61 \mathrm{abc}$ & 2,17 \\
\hline 5 & H5-2205 & $1,08 \mathrm{~g}$ & $1,19 \mathrm{~d}$ & 1,85 cdef & $2,47 \mathrm{~cd}$ & $1,83 \mathrm{~g}$ & 1,68 \\
\hline 6 & DT 19 G1-2 & 3,00 a & 1,66 abc & 2,94 a & $2,80 \mathrm{ab}$ & 2,54 abcd & 2,59 \\
\hline 7 & CK 6 G1-3 & $1,71 \mathrm{f}$ & $1,75 \mathrm{a}$ & $2,54 \mathrm{~b}$ & $2,08 \mathrm{e}$ & 2,16 ef & 2,05 \\
\hline 8 & DT 16 G1 & $2,84 \mathrm{ab}$ & $1,62 \mathrm{abc}$ & $2,87 \mathrm{a}$ & $2,62 \mathrm{bc}$ & 2,39 bcdef & 2,47 \\
\hline 9 & DT 17 G1 & $2,63 \mathrm{bc}$ & 1,59 abc & $2,54 \mathrm{~b}$ & $2,92 \mathrm{a}$ & 2,55 abcd & 2,45 \\
\hline 10 & DT $18 \mathrm{G} 1$ & $2,87 \mathrm{ab}$ & $1,66 \mathrm{abc}$ & $2,79 \mathrm{a}$ & $2,92 \mathrm{a}$ & 2,47 abcd & 2,54 \\
\hline 11 & UNPAD CK 12 & 1,87 ef & $1,65 \mathrm{abc}$ & $1,33 \mathrm{~g}$ & $2,40 \mathrm{~cd}$ & $2,23 \mathrm{def}$ & 1,9 \\
\hline 12 & UNPAD KA 2 & $2,28 \mathrm{~cd}$ & $1,53 \mathrm{abc}$ & 1,69 ef & $2,28 \mathrm{de}$ & $2,36 \mathrm{cdef}$ & 2,03 \\
\hline 13 & UNPAD CK 5 & $1,80 \mathrm{f}$ & $1,43 \mathrm{~cd}$ & $1,37 \mathrm{~g}$ & $2,25 \mathrm{de}$ & 2,19 ef & 1,81 \\
\hline 14 & UNPAD KA 6 & $2,21 \mathrm{de}$ & $1,62 \mathrm{abc}$ & $1,77 \mathrm{def}$ & $2,47 \mathrm{~cd}$ & $2,70 \mathrm{ab}$ & 2,15 \\
\hline 15 & UNPAD CK 6 & $1,84 \mathrm{f}$ & $1,64 \mathrm{abc}$ & $1,64 \mathrm{f}$ & $2,45 \mathrm{~cd}$ & $2,26 \mathrm{def}$ & 1,97 \\
\hline 16 & Cikuray & 1,86 ef & $1,78 \mathbf{a}$ & 1,71 ef & $2,46 \mathrm{~cd}$ & $2,12 \mathrm{fg}$ & 1,99 \\
\hline \multirow[t]{4}{*}{17} & Detam 1 & $2,79 a b$ & $1,69 a b$ & $2,42 \mathrm{~b}$ & $2,82 \mathrm{ab}$ & $2,74 \mathrm{a}$ & 2,49 \\
\hline & Rerata (t/ha) & 2,14 & 1,60 & 2,09 & 2,53 & 2,37 & \\
\hline & KK \% & 11,52 & 11,00 & 8,35 & 7,88 & 9,68 & \\
\hline & BNT 5\% & 0,35 & 0,25 & 0,24 & 0,28 & 0,32 & \\
\hline
\end{tabular}

KETERANGAN:

Angka-angka pada kolom yang tidak diikuti oleh huruf kecil yang sama menunjukkan berbeda nyata pada uji lanjut BNT 5\%

Tabel 2 pelaksanaan uji adaptasi di 5 lokasi pada tanam musim hujan (MH) terhadap produksi biji terlihat bahwa masing-masing lokasi seperti di Cianjur Jawa Barat dari 15 galur materi uji, memiliki kisaran produksi biji antara 1,08-3,00 t/ha sedangkan kedua tanaman kontrol 1,86-2,79 t/ha. Galur DT19 G1-2 memiliki produksi biji tertinggi yaitu 3,00 t/ha, berbeda nyata lebih tinggi taraf 5\%, analisis BNT 0,25 dengan KK 11\%. Galur DT19 G1-2 dan DT17 G1 produksi bijinya rendah 1,66 t/ha dan 1,59 t/ha dan hasilnya tidak berbeda nyata dibandingkan dengan kontrol varietas Cikuray 1,78 t/ha dan Detam 1 kontrol nasional 1,69 t/ha. Rata-rata produksi biji di lokasi ini $1,60 \mathrm{t} / \mathrm{ha}$. 


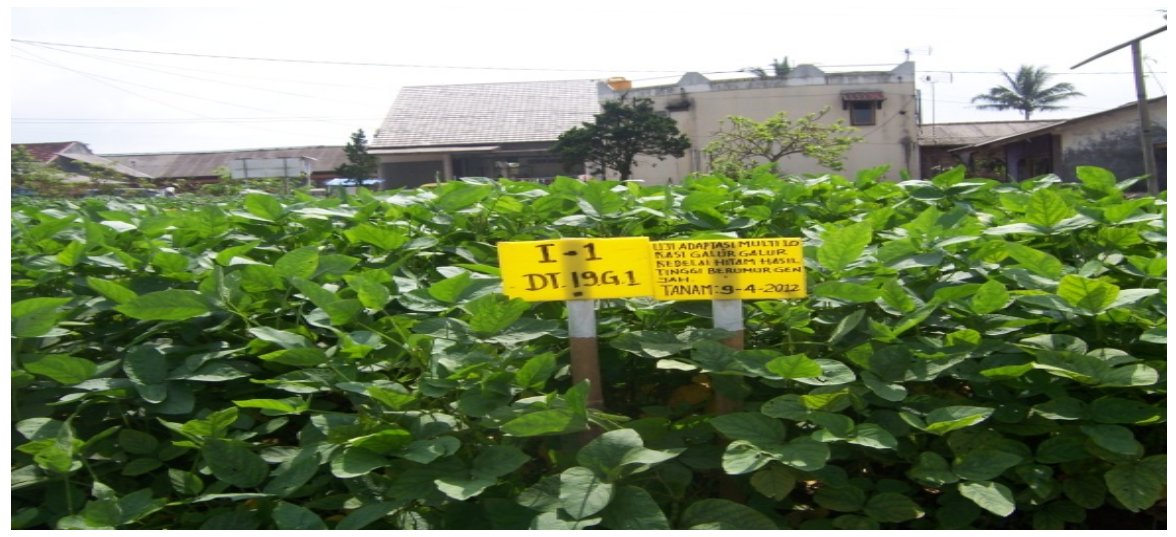

Gambar 1. Uji adaptasi genotip kedelai hitam lokasi di Cianjur

Lokasi Majalengka Jawa Barat menunjukkan berbeda nyata menurut uji $\mathrm{F}$ pada taraf $5 \%$, dengan KK 8,35 \% dan BNT 5\% 0,24. Produksi biji Galur DT19 G1-2 memiliki potensi hasil lebih tinggi yaitu 2,94 t/ha dan hasilnya berbeda nyata lebih tinggi dibandingkan varietas kontrol Cikuray (1,71 t/ha) dan Detam 1 (2,42 t/ha). Produksi biji galur DT17 G1 (2,54 t/ha) berbeda nyata lebih tinggi dibandingkan dengan varietas kontrol Cikuray dan tidak berbeda nyata dibandingkan dengan kontrol nasional varietas Detam 1. Ratarata produksi biji dilokasi ini 2,09 t/ha.

Lokasi Yogyakarta Jawa Tengah semua galur memiliki produksi biji kisaran antara 2,08 t/ha-2,92 t/ha. Produksi biji galur DT17 G1 (2,92 t/ha) dan DT19 G1-2 (2,80 t/ha) berbeda nyata

Tabel 3. Produksi biji uji adaptasi pada musim kemarau (MK) di 5 lokasi percobaan

\begin{tabular}{|c|c|c|c|c|c|c|c|}
\hline \multirow{3}{*}{ No } & \multirow{3}{*}{$\begin{array}{l}\text { Nama galur/ } \\
\text { varietas }\end{array}$} & \multicolumn{5}{|c|}{ PRODUKSI BIJI (t/ha) } & \multirow{3}{*}{$\begin{array}{c}\text { Rerata } \\
\text { gabungan } \\
\text { (t/ha) }\end{array}$} \\
\hline & & \multicolumn{5}{|c|}{ MK $(2010)$} & \\
\hline & & $\begin{array}{c}\text { Madiun } \\
\text { Jawa Timur }\end{array}$ & $\begin{array}{c}\text { Ngawi } \\
\text { Jawa Timur }\end{array}$ & $\begin{array}{c}\text { Cirebon } \\
\text { Jawa Barat }\end{array}$ & $\begin{array}{c}\text { Karawang } \\
\text { Jawa Barat }\end{array}$ & $\begin{array}{l}\text { Indramayu } \\
\text { Jawa Barat }\end{array}$ & \\
\hline 1 & H1-1051 & $2,24 \mathrm{ab}$ & $1,84 \mathrm{bc}$ & $2,23 \mathrm{~cd}$ & $1,78 \mathrm{def}$ & 0,88 fghi & 1,79 \\
\hline 2 & $\mathrm{H} 2-662$ & $2,08 \mathrm{bc}$ & $1,55 \mathrm{c}$ & $2,02 \mathrm{~d}$ & 1,61 ef & $0,80 \mathrm{hi}$ & 1,62 \\
\hline 3 & H3-1811 & $2,20 \mathrm{ab}$ & $1,92 \mathrm{ab}$ & $2,04 \mathrm{~d}$ & 1,62 ef & $0,81 \mathrm{ghi}$ & 1,72 \\
\hline 4 & H4-1844 & $2,13 \mathrm{bc}$ & $1,87 \mathrm{abc}$ & $1,87 \mathrm{~d}$ & $1,49 \mathrm{f}$ & $0,74 \mathrm{i}$ & 1,62 \\
\hline 5 & H5-2205 & $1,72 \mathrm{e}$ & $1,77 \mathrm{bc}$ & $2,33 \mathrm{~cd}$ & $1,86 \mathrm{de}$ & 0,92 efgh & 1,72 \\
\hline 6 & DT 19 G1-2 & $2,22 \mathrm{ab}$ & $2,1 \mathbf{a b}$ & 3,17 a & 2,52 ab & 1,25 a & 2,25 \\
\hline 7 & CK 6 G1-3 & $2,10 \mathrm{bc}$ & $2,09 \mathrm{ab}$ & $2,00 \mathrm{~d}$ & 1,59 ef & 0,79 hi & 1,71 \\
\hline 8 & DT 16 G1 & $2,19 \mathrm{abc}$ & $2,02 \mathrm{ab}$ & $3,23 \mathrm{a}$ & $2,57 \mathrm{a}$ & $1,27 \mathrm{a}$ & 2,26 \\
\hline 9 & DT 17 G1 & $2,25 \mathrm{ab}$ & $2,06 \mathrm{ab}$ & 3,04 a & $2,42 \mathrm{ab}$ & $1,20 \mathrm{ab}$ & 2,19 \\
\hline 10 & DT 18 G1 & $2,39 \mathrm{a}$ & $1,88 \mathrm{abc}$ & $2,92 \mathrm{ab}$ & $2,40 \mathrm{ab}$ & $1,07 \mathrm{ab}$ & 2,13 \\
\hline 11 & UNPAD CK 12 & $2,03 \mathrm{bcd}$ & $2,20 \mathrm{a}$ & $2,15 \mathrm{~d}$ & $1,88 \mathrm{de}$ & 0,93 efgh & 1,84 \\
\hline 12 & UNPAD KA 2 & $2,14 \mathrm{bc}$ & $1,95 \mathrm{ab}$ & $2,38 \mathrm{bcd}$ & $1,95 \mathrm{~cd}$ & $0,96 \mathrm{def}$ & 1,88 \\
\hline 13 & UNPAD CK 5 & $2,10 \mathrm{bc}$ & $1,80 \mathrm{bc}$ & $2,27 \mathrm{~cd}$ & $1,78 \mathrm{def}$ & 0,88 fghi & 2,04 \\
\hline 14 & UNPAD KA 6 & $2,40 \mathrm{a}$ & $1,97 \mathrm{ab}$ & $2,73 \mathrm{abc}$ & $2,07 \mathrm{~cd}$ & $1,02 \mathrm{def}$ & 2,04 \\
\hline 15 & UNPAD CK 6 & 2,09 cde & $2,21 \mathrm{a}$ & $2,06 \mathrm{~d}$ & $1,95 \mathrm{~cd}$ & 0,96 def & 1,85 \\
\hline 16 & Cikuray & $1,97 \mathrm{~cd}$ & $2,06 \mathrm{ab}$ & $1,92 \mathrm{~d}$ & 1,89 de & 0,93 efgh & 1,75 \\
\hline \multirow[t]{4}{*}{17} & Detam 1 & $1,83 \mathrm{de}$ & 2,07 ab & 2,38 bcd & $2,22 \mathrm{bc}$ & 1,10 abc & 1,92 \\
\hline & Rerata (t/ha) & 2,12 & 1,96 & 2,4 & 1,96 & 0,97 & \\
\hline & KK \% & 7,59 & 12,37 & 16,22 & 11,03 & 11,23 & \\
\hline & BNT 5\% & 0,22 & 0,34 & 0,55 & 0,31 & 0,15 & \\
\hline
\end{tabular}

KETERANGAN:

Angka-angka pada kolom yang tidak diikuti oleh huruf kecil yang sama menunjukkan berbeda nyata pada uji lanjut BNT 5\% 
lebih tinggi dibandingkan dengan kontrol tetuanya varietas Cikuray $(2,46 \mathrm{t} / \mathrm{ha})$ tetapi tidak berbeda nyata dibandingkan dengan kontrol nasional varietas Detam 1 (2,82 t/ha). Rata-rata produksi biji dilokasi ini mencapai 2,53 t/ha.

Lokasi Banyuwangi Jawa Timur semua galur memiliki produksi biji kisaran antara 1,83 t/ha-2,70 t/ha. KK 9,68\% dan BNT 5\% 0,32. Produksi biji galur DT17 G1 (2,55 t/ha) dan DT19 G1-2 (2,54 t/ha) berbeda nyata lebih tinggi dibandingkan dengan kontrol tetua varietas
Lokasi Ngawi Jawa Timur semua galur memiliki produksi biji kisaran antara 1,55- 2,21 t/ha, KK $12,37 \%$ dan BNT 0,34. Tingkat produktivitas lahan di Ngawi relatif rendah, Produktivitas hasil biji galur DT19 G1-2 (2,10 t/ha) dan DT17 G1 (2,06 t/ha) tidak berbeda nyata dibandingkan dengan tetua varietas Cikuray $(2,06$ $\mathrm{t} / \mathrm{ha})$ dan kontrol nasional Detam 1 (2,07t/ha). Rata-rata produksi biji dilokasi ini 1,96 t/ha. Uji adaptasi genotip kedelai hitam lokasi di Ngawi Jawa Timur pada Gambar 2.

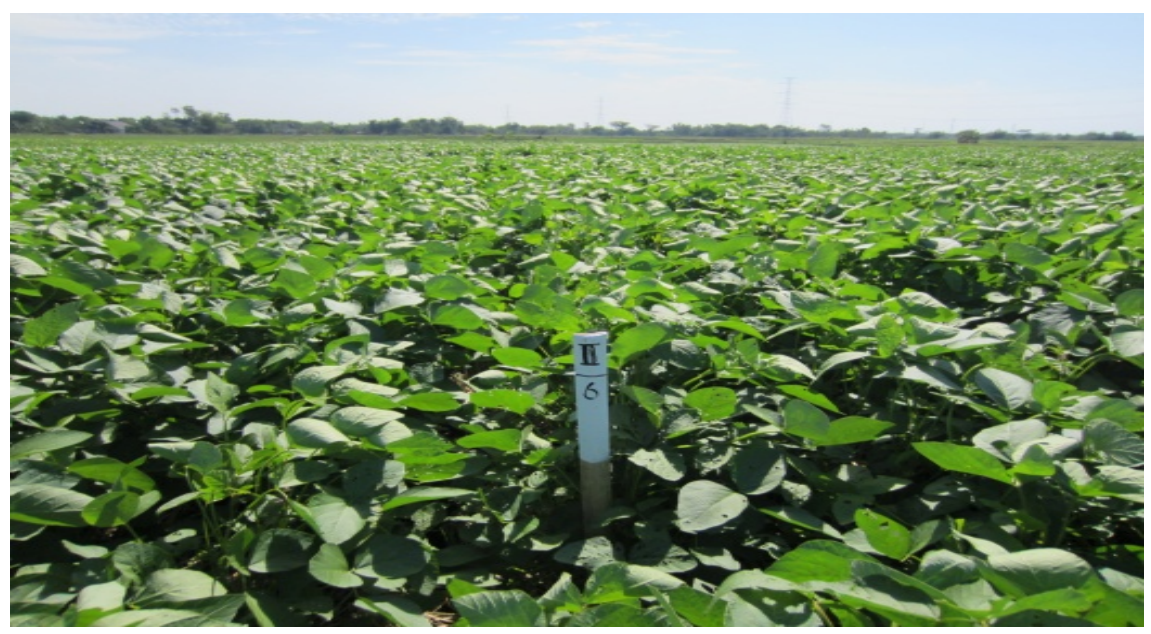

Gambar 2. Uji adaptasi galur kedelai hitam lokasi di Ngawi

Cikuray (2,12 t/ha), dan tidak berbeda nyata dibandingkan dengan kontrol nasional varietas Detam $1 \quad(2,74 \mathrm{t} / \mathrm{ha})$. Rata-rata produksi biji dilokasi ini mencapai 2,37 t/ha.

Tabel 3 pelaksanaan uji adaptasi di 5 lokasi pada tanam musim kemarau (MK) terhadap produksi biji terlihat bahwa masing-masing lokasi seperti di Madiun Jawa Timur dari 15 galur materi uji, memiliki kisaran produksi biji antara 1,72-2,40 t/ha sedangkan kedua tanaman kontrol 1,83-1,97 tha. Galur DT19 G1-2 memiliki produksi biji yaitu 2,22 t/ha, berbeda nyata lebih tinggi dibandingkan dengan kontrol varietas Cikuray $(1,97 \mathrm{t} / \mathrm{ha})$ dan Detam $1(1,83 \mathrm{t} / \mathrm{ha})$, sedangkan galur DT17 G1 memiliki produksi biji 2,25 t/ha berbeda nyata lebih tinggi dibandingkan dengan kontrol varietas Cikuray dan dengan varietas Detam 1 kontrol nasional. Rata-rata tingkat produksi biji dilokasi ini mencapai 2,12 t/ha.
Lokasi Cirebon Jawa Barat semua galur memiliki produksi biji tinggi dengan KK 16,22 \% dan BNT 5\% 0,55. Produksi biji Galur DT19 G1-2 memiliki potensi hasil tertinggi yaitu 3,17 t/ha dan hasilnya berbeda nyata dibandingkan varietas kontrol Cikuray (1,92 t/ha) dan Detam 1 (2,38 t/ha). Produksi biji galur DT17 G1 (3,04 t/ha) berbeda nyata lebih tinggi dibandingkan dengan varietas kontrol Cikuray dan kontrol nasional varietas Detam 1. Rata-rata produksi biji dilokasi ini mencapai $2,4 \mathrm{t} / \mathrm{ha}$.

Lokasi Karawang Jawa Barat semua galur memiliki produksi biji kisaran antara 1,49 t/ha2,57 t/ha. KK 11,03\% dan BNT 5\% 0,31. Produksi biji galur DT17 G1 (2,42 t/ha) dan DT19 G1-2 (2,52 t/ha) berbeda nyata dibandingkan dengan kontrol tetuanya varietas Cikuray $(1,89$ $\mathrm{t} / \mathrm{ha})$ tetapi tidak berbeda nyata dibandingkan dengan kontrol nasional varietas Detam 1 (2,22 t/ha). Rata-rata produksi biji dilokasi ini 1,96 t/ha. 
Lokasi Indramayu Jawa Barat semua galur memiliki produksi biji sangat rendah kisaran antara $0,74 \mathrm{t} / \mathrm{ha}-1,27 \mathrm{t} / \mathrm{ha}$. KK $11,23 \%$ dan BNT 5\% 0,15. Produksi biji galur DT17 G1 (1,20 t/ha) dan DT19 G1-2 (1,25 t/ha) berbeda nyata dibandingkan dengan kontrol tetua varietas Cikuray $(0,93 \mathrm{t} / \mathrm{ha})$, dan tidak berbeda nyata dibandingkan dengan kontrol nasional varietas Detam 1 (1,10 t/ha). Rata-rata produksi biji dilokasi ini sangat rendah $0,97 \mathrm{t} / \mathrm{ha}$. tumbuhnya. Potensi hasil akan mencapai maksimal jika kedua faktor tersebut telah memenuhi syarat bagi kebutuhan tanamannnya. Menurut Djaelani et al., [9] bahwa ekspresi tanaman sering dipengaruhi oleh faktor lingkungan.

Produktivitas hasil biji kedelai ditentukan oleh faktor komponennya, antara lain tinggi tanaman, jumlah polong, jumlah cabang maupun ukuran bijinya. Galur kedelai yang mempunyai

Tabel 4. Rerata ranking gabungan produksi biji dari 10 lokasi percobaan pada musim hujan (MH) dan musim kemarau (MK)

\begin{tabular}{|c|c|c|c|c|c|}
\hline \multirow[t]{2}{*}{ No } & \multirow{2}{*}{$\begin{array}{c}\text { Nama } \\
\text { Galur/varietas }\end{array}$} & \multicolumn{2}{|c|}{$\begin{array}{l}\text { Produksi biji } \\
\text { (t/ha) }\end{array}$} & \multirow{2}{*}{$\begin{array}{c}\text { Rerata } \mathrm{MH} \text { dan } \mathrm{MK} \\
\text { (t/ha) }\end{array}$} & \multirow[t]{2}{*}{ Ranking } \\
\hline & & $\mathrm{MH}$ & MK & & \\
\hline 1 & H1-1051 & 2,05 & 1,79 & 1,92 & 10 \\
\hline 2 & H2-662 & 2,02 & 1,62 & 1,82 & 16 \\
\hline 3 & H3-1811 & 2,21 & 1,72 & 1,97 & 7 \\
\hline 4 & H4-1844 & 2,17 & 1,62 & 1,90 & 12 \\
\hline 5 & H5-2205 & 1,68 & 1,72 & 1,70 & 17 \\
\hline 6 & DT 19 G1-2 & 2,59 & 2,25 & 2,42 & 1 \\
\hline 7 & CK 6 G1-3 & 2,05 & 1,71 & 1,88 & 13 \\
\hline 8 & DT 16 G1 & 2,47 & 2,26 & 2,37 & 2 \\
\hline 9 & DT 17 G1 & 2,45 & 2,19 & 2,32 & 4 \\
\hline 10 & DT $18 \mathrm{G} 1$ & 2,54 & 2,13 & 2,34 & 3 \\
\hline 11 & UNPAD CK 12 & 1,90 & 1,84 & 1,87 & 14 \\
\hline 12 & UNPAD KA 2 & 2,03 & 1,88 & 1,96 & 8 \\
\hline 13 & UNPAD CK 5 & 1,81 & 2,04 & 1,93 & 9 \\
\hline 14 & UNPAD KA 6 & 2,15 & 2,04 & 2,10 & 6 \\
\hline 15 & UNPAD CK 6 & 1,97 & 1,85 & 1,91 & 11 \\
\hline 16 & Cikuray & 1,99 & 1,75 & 1,87 & 15 \\
\hline \multirow[t]{2}{*}{17} & Detam 1 & 2,49 & 1,92 & 2,21 & 5 \\
\hline & Rerata (t/ha) & 2,15 & 1,90 & & \\
\hline
\end{tabular}

Tabel 4 berdasarkan hasil rata-rata gabungan dari 10 lokasi pada tanam musim hujan (MH) dan musim kemarau (MK) terlihat bahwa galur DT19 G1-2 menduduki ranking pertama yaitu memiliki produktivitas rata-rata 2,42 t/ha, sedangkan galur H5-2205 menduduki ranking terendah produktivitasnya yaitu 1,70 t/ha. Galur DT19 G1-2, DT16 G1, DT18 G1 dan DT18 G1 mempunyai rata-rata hasil biji lebih tinggi (> 2,30 t/ha) dibandingkan dengan varietas Cikuray (tetua) dan Detam 1 kontrol nasional. Setiap lokasi pengujian memiliki tingkat produktivitas hasil biji yang berbeda, hasil analisis diperolah minimal terdapat 2 galur yang berbeda. Hal ini berindikasi respon galur yang diuji mempunyai tingkat produktivitas hasil biji berbeda-beda. Potensi hasil tanaman ditentukan oleh genetik dan lingkungan jarak buku subur yang relatif pendek dan ditunjang oleh batang yang tinggi, jumlah polong banyak diprediksi memiliki potensi hasil yang tinggi (>3,5 t/ha). Menurut Ambarwati dan Murti [10], jika suatu sifat tanaman yang berkorelasi positif nyata terhadap hasil biji, namun terdapat komponen lain yang mempengaruhi, hal tersebut disebabkan oleh adanya efek tidak langsung melalui komponen hasil lainnya. Berdasarkan sumber keragaman yang diajukan seluruh komponen menunjukkan berbeda nyata pada taraf uji F 5\%. Lokasi yang nyata mengindikasikan bahwa terdapat perbedaan produktivitas lokasi. Komponen sumber keragaman interaksi genotip dengan lokasi yang berbeda nyata (uji F 5\%), mengisyaratkan bahwa terjadi perbedaan produktivitas hasil biji pada setiap genotip 
maupun lokasi. Interaksi Lokasi x Genotip yang nyata mengindikasikan bahwa terdapat perbedaan keunggulan genotip pada lokasi yang berbeda. Respon genotip akibat terjadinya interaksi Lokasi $x$ Genotip yang berpengaruh terhadap hasil biji, dimana hasil biji kedelai berkaitan erat dengan lokasi Pengujian [11]. Pemetaan galur akan lebih diterima oleh tanaman [15]. Tanaman yang tinggi relatif tidak diikuti oleh jumlah polongnya. Galur DT19 G1-2 mempunyai jumlah polong 55 dan galur DT17 G1 mempunyai jumlah polong 53. Semakin banyak polong, semakin banyak biji yang dihasilkan [16].

Tabel 5. Rerata karakter agronomi kedelai hitam yang di uji adaptasi di 10 lokasi.

\begin{tabular}{clcccc}
\hline No & \multicolumn{1}{c}{ Galur/varietas } & $\begin{array}{c}\text { Umur Panen } \\
\text { (hari) }\end{array}$ & $\begin{array}{c}\text { Tinggi Tanaman } \\
(\mathrm{cm})\end{array}$ & $\begin{array}{c}\text { Jumlah Polong } \\
(\text { buah })\end{array}$ & $\begin{array}{c}\text { Berat 100 Biji } \\
(\mathrm{g})\end{array}$ \\
\hline 1 & H1-1051 & 79 & 55,0 & 58 & 11,01 \\
2 & H2-662 & 82 & 54,8 & 58 & 10,66 \\
3 & H3-1811 & 80 & 57,2 & 53 & 10,16 \\
4 & H4-1844 & 82 & 55,5 & 54 & 11,86 \\
5 & H5-2205 & 83 & 46,9 & 51 & 12,16 \\
6 & DT19 G1-2 & $\mathbf{8 4}$ & $\mathbf{5 6 , 8}$ & $\mathbf{5 5}$ & $\mathbf{1 3 , 1 5}$ \\
7 & CK 6 G1-3 & 82 & 53,2 & 56 & 10,87 \\
8 & DT 16 G1 & 87 & 54.7 & 57 & 12,93 \\
9 & DT17 G1 & $\mathbf{8 7}$ & $\mathbf{5 6 , 0}$ & $\mathbf{5 3}$ & 13,302 \\
10 & DT 18 G1 & 84 & 53,7 & 53 & 11,28 \\
11 & UNPAD CK 12 & 78 & 57,3 & 55 & 9,95 \\
12 & UNPAD KA 2 & 82 & 63,2 & 57 & 10,71 \\
13 & UNPAD CK 5 & 79 & 57,1 & 57 & 10,18 \\
14 & UNPAD KA 6 & 82 & 60,4 & 58 & 10,54 \\
15 & UNPAD CK 6 & 78 & 56,3 & 59 & 10,81 \\
16 & Cikuray & 83 & 53,7 & 60 & 12,68 \\
17 & Detam 1 & 89 & 56,9 & 51 & 11,49 \\
\hline
\end{tabular}

sulit jika terjadi interaksi Lokasi x Genotip, urutan genotip akan berbeda di lingkungan yang berbeda [12].

Interaksi genotip dengan lingkungan penting diketahui untuk menentukan wilayah adaptasi suatu genotip pada lingkungan tertentu [13]. Mengukur peran faktor lingkungan terhadap potensi genetik genotip [14], serta berguna dalam menentukan adaptabilitas dan stabilitas suatu genotip. Interaksi Lingkungan x Genotip sejalan dengan nilai indek lingkungan mulai bernilai negatif hingga positif yang rentangnya relatif besar. Untuk mengetahui tingkat stabilitas hasil biji di seluruh lokasi maka dapat dianalisis menggunakan metode regresi.

Tabel 5 rata-rata tinggi tanaman berkisar antara 46,9-63,2 cm, galur DT19 G1-2 memiliki tinggi tanaman 56,8 cm sedangkan galur DT17 G1 $58,0 \mathrm{~cm}$. Faktor penting yang dapat mempengaruhi hasil kedelai adalah cahaya yang
Galur DT17 G1 mempunyai ukuran biji 13,30 g/100 butir dan galur DT19 G1-2 mempunyai ukuran biji 13,15 g/100 butir terbesar dari 17 genotip yang diuji pada Tabel 5. Kedelai berukuran biji besar dengan kandungan protein tinggi penting untuk bahan baku industri [17]. Karakteristik tersebut pada umumnya diminati industri tempe. Untuk produk olahan kedelai hitam menjadi kecap, ukuran biji kecil hingga sedang lebih efektif dalam proses fermentasinya. Tanaman kedelai umumnya memiliki jumlah polong banyak, tetapi ukuran bijinya menjadi lebih kecil. Galur DT17 G1 dan DT19 G1-2 memiliki jumlah polong lebih sedikit dan berukuran biji lebih besar dibandingkan dengan varietas Cikuray yang mempunyai polong lebih banyak tetapi berukuran biji lebih kecil pada Tabel 3. Ukuran biji merupakan karakteristik penting pada produksi kedelai [18]. 


\section{KESIMPULAN}

Dari uraian di atas dapat disimpulkan sebagai berikut :

Galur DT17 G1 memiliki potensi hasil biji tinggi 3,03 t/ha dengan rata- rata hasil 2,32 t/ha, rata-rata umur panen 87 hari, ukuran biji besar dengan berat rata-rata $13,30 \mathrm{~g} / 100 \mathrm{biji}$, mampu berproduksi optimal pada rentang lingkungan yang relatif luas.

Galur DT19 G1-2 memiliki potensi hasil biji tinggi 3,17 t/ha dengan rata-rata hasil 2,42 t/ha, rata-rata umur panen 84 hari, ukuran biji besar dengan berat rata-rata $13,15 \mathrm{~g} / 100 \mathrm{biji}$, beradaptasi khusus dikembangkan pada daerah/lahan yang subur.

Galur mutan DT17 G1 dan DT19 G1-2 dapat diajukan untuk dievaluasi dan diusulkan untuk dilepas sebagai varietas unggul baru kedelai hitam yang mampu berproduksi tinggi dan berbiji besar.

\section{UCAPAN TERIMA KASIH}

Penulis mengucapkan terima kasih kepada : BALITKABI Malang Badan Litbang Kementrian Pertanian dan PAIR-BATAN Jakarta yang telah mendanai program uji adaptasi dalam bentuk program konsorsium kedelai.

Fakultas Pertanian Universitas Padjadjaran (UNPAD) Bandung sebagai mitra dalam program konsorsium penelitian kedelai.

Pemulia kedelai PAIR-BATAN : Bapak Harry Is Mulyana, S.IP, Dr. Masrizal dan semua pihak yang telah membantu kegiatan penelitian, pengujian, uji adaptasi dan lain-lain sehingga penulis dapat membuat tulisan ini.

\section{DAFTAR PUSTAKA}

1. Warisno dan K. Dahana, Meraup untung dari olahan kedelai, Agro Media Pustaka, Cet 1, Jakarta, 13, 2010.

2. Damardjati, D.S., S. Widowati dan H. Taslim. Soybean Processing and Utilization in Indonesia. Indon. Agric. Res. Devel. J., vol. 18, no. 1, pp. 13-25, 1966.
3. Ginting, E S.S. Antarlina dan S. Widowati. Varietas Kedelai Unggul untuk Bahan Baku Industri Pangan. J. Penelitian dan Pengembangan Pertanian, vol. 28, no. 3, pp. 79-87, 2009.

4. Purwanti, S. Kajian Suhu Ruang Simpan Terhadap Kualitas Benih Kedelai Hitam dan Kedelai Kuning. Ilmu Pertanian, vol. 11, no. 1, pp. 22-31, 2004.

5. Arwin, Galur Mutan Harapan Kedelai Super Genjah Q-298 dan 4-Psj, J. Ilm. Apl. Isot. dan Radiasi, vol. 8, no. 2, Jakarta, pp. 107-116, 2012.

6. Adie, M.M. dan A. Krisnawati, Biologi Tanaman Kedelai. Dalam, Kedelai Teknik Produksi dan Pengembangan. Puslitbangtan. pp. 45-73, 2007.

7. Mulyana, I. H., Arwin, Tarmizi dan Masrizal, Uji adaptasi, uji ketahanan terhadap penyakit dan hama penting serta analisis nutrisi galur-galur mutan harapan kedelai umur sedang dan genjah berukuran biji besar, Prosiding Seminar Hasil Penelitian Aplikasi Isotop dan Radiasi, Jakarta, 02 Desember 2010, 1328, 2010.

8. Sobrizal, Potensi Pemuliaan Mutasi untuk Perbaikan Varietas PadiLokal Indonesia, J. Ilm. Apl. Isot. dan Radiasi, vol. 12, no. 1, Jakarta, pp. 23-35, 2016.

9. Djaelani A. K., Nasrullah dan Soemartono, InteraksiGxE, adaptabilitas dan stabilitas galur-galur kedelai dalam uji multilokasi. Zuriat., 12, 27-33, 2001.

10. Ambarwati, E. Dan H. Murti. Analisis Korelasi dan KoefisienLintas Sifat-sifat Agronomi terhadap Komposisi Kimia Umbi Iles-iles (Amophophallus variabilis). Ilmu Pertanian. vol. 8, no. 2, pp. 55-61, 2001.

11. Vollmann, J. J. Winkler, C.N. Fritz, H. Grausgruber and P. Ruckenbauruer. Spatial Field Variation in Soybean (Glycinemax [L.] Merr). Ferformance Trial Affectagronomic Character and 
Seed Composition. http:/www.sciencedirect.com/ science, 2000 .

12. Kaya, Y., Palta and S. Taner. Additive Main Effects and Multiplicative Interactions Analysis of Yield Performances in Bread Wheat Genotypes Across Environments. Turk J. Agric For, vol. 26, pp. 275-279, 2002.

13. Sneller, C.H., L. Kilgore Norquest, and D. Dombek. Repeatability Statistics in Soybean. Crop. Sci. vol. 37, pp. 383390, 1997.

14. Rao, M.S.S., B.G. Mullinix, M. Rangappa, E. Cibert, A.S.Bhagsari, V.T. Sapra, J.M. Joshi, and R.B. Dadson. Genotype $\mathrm{x}$ Environment Interactions and yield Stability of Food grade Soybean Genotypes. Agron. J. Vol. 94, pp. 72-80, 2002.
15. Jomol, P. M., S. J. Herbert, S. Zhang, A. A. F. Rautenkranz, \& G. V. Lichfield. Diffrential renponse of soybean yield components to the timing of light enrichment. Agron. J. vol. 92, pp. 11561161, 2000.

16. Bravo, J.A. W.R. Fehr and S.R. De Cianzio. Use of pod width for indirect selection of seed wight in soybeans. Genet. Mol. Biol. vol. 22, pp. 229-232, 1980.

17. Brian, J.A., W.R. Fehr and G.A. Welke. Selection for large seed and high protein in two and three parent soybean population. Crop Sci. vol. 42, pp. 18761881, 2002.

18. Susan L. Jonson, W.R. Fehr, G.A. Welke, and S.R. Cianzio. Genetic variability for seed size of two and three parent soybean population. Crop Sci. vol. 41, pp. 1029-1033, 2001. 